\title{
Comparative Study of Conventional and Modified Solar Still with Inbuilt Condenser and Agitation Effect
}

\author{
Ashok Babu B ${ }^{1}$, Balakumaresan $\mathrm{S}^{2}$, Chandra Mohan $\mathrm{P}^{3}$, Mani Prabhu $\mathrm{R}^{4}$, Arun Kumar $\mathrm{R}^{5}$ \\ ${ }^{1,2,3,4}$ Final year students, Department of Mechanical Engineering, Ramco Institute of Technology, \\ Rajapalayam, Tamilnadu, India - 626117
}

${ }^{5}$ Assistant Professor, Department of Mechanical Engineering, Ramco Institute of Technology, Rajapalayam, Tamilnadu, India - 626117

Abstract

The demand for fresh water production is growing day by day with the increase in world population and with industrial growth. Use of desalination technology is increasing to meet this demand. Desalination is one of the methods to convert brackish water to fresh water. Among desalination technologies, solar still requires low maintenance and are readily affordable; however, their productivity is limited. Solar still yields only lower amount of fresh distillate by using solar energy, when compared to other conventional based desalination system. Two stills, Conventional solar still (CSS) and Modified solar still (MSS) with agitator and inbuilt condenser, were constructed and tested under same environmental conditions. Through this modified solar still, enough potable water per person can be produced when compared to conventional solar still. The experimental result shows that the modified still enhanced the distillate productivity as twice as compared to the conventional still. Also modified still is more economical than the conventional still.

Keywords

The conventional still is modified with water agitating system and inbuilt condenser, A shaft coupled with a dc motor and inbuilt condenser used for agitating of water and increases the condensation rate,
The agitation of basin water breaks the boundary layer of water and increase the area of contact with air, The inbuilt condenser increases the area of contact for condensation which further increases the productivity, The productivity was enhanced as twice as compared with conventional still.

\section{INTRODUCTION}

Water is one of the basic needs. The demand of fresh water is increasing day by day. India occupies $2 \%$ of the world's land area, represents $16 \%$ of the world population and $15 \%$ of livestock, whereas it has only $4 \%$ of the water resources of the world. India ranks $133^{\text {rd }}$ out of 180 nations for its water availability. Ministry of Water Resources reports that, per capita water availability in $2025 \& 2050$ will come down by $36 \%$ and $60 \%$ respectively of the 2001 levels. Figure 1 shows the per capita availability statistics in India [1].

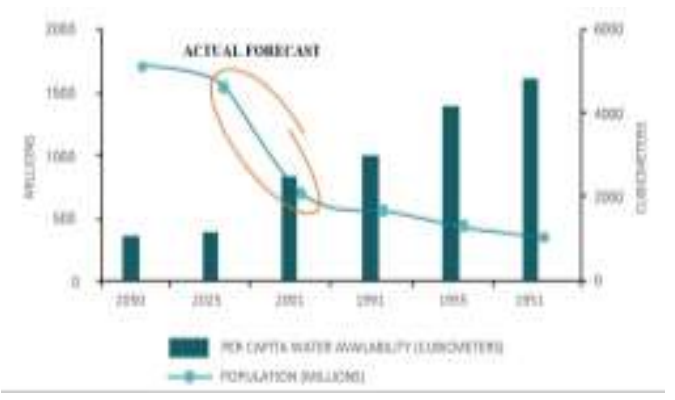

Figure 1. Per capita water availability in India 
The availability of fresh water in India has fallen around $2309 \mathrm{~m}^{3} /$ capita/annum in 1991 to $1902 \mathrm{~m}^{3} /$ capita/annum in 2001 . The projected availability by the year $\mathbf{2 0 2 5}$ is likely to drop below $1500 \mathrm{~m}^{3} /$ capita/annum. United Nation reports that more than three million people in world die due to water-borne diseases each year including 1.2 million children. India is ranked 120 among 122 nations in terms of quality of water provided to citizens [2]. Thus providing quality fresh water becomes need of the time.

\section{OBJECTIVE}

The objective of this research work is to improve the yield of potable water by optimizing the speed agitator and also to improve the condensation process by providing inbuilt condenser. To achieve the objectives, the following sub tasks are performed through the experimental investigations.

- To design and fabricate the conventional solar still and modified solar still with agitator and inbuilt condenser.

- To analyses and compare the performance of both the stills.

- To investigate the properties of the fresh water obtained from the solar still.

\section{DESALINATION}

Desalination is one of the methods to convert brackish water in to fresh water. Solar still is a device which does so using solar energy. The problem associated with solar still is its least productivity. Solar radiation intensity, collector area, thickness of glass cover plate, basin water depth, insulation, angle of inclination, wind velocity are the major parameters that affects solar still productivity [3]. Productivity of the still can be improved by enhancing the evaporation and condensation rate. Increase in inlet water temperature and increase in wind speed will improve the evaporation rate and condensation rate of the still respectively [4]. Increasing difference between water and glass temperature will improve the productivity of still [5]. Cooling of glass cover increases the productivity of still from $15.5 \%$ to $20 \%$ [6]. Still with agitation effect and external condenser have shown $39.49 \%$ more productivity than conventional still [7]. Still with water nano fluid and side walls painted white, have produced a yield of 3,445 $\mathrm{ml} / \mathrm{m}^{2} /$ day and $3,058 \mathrm{ml} / \mathrm{m}^{2} /$ day for the water depth of $5 \mathrm{~cm}$ and $10 \mathrm{~cm}$ respectively. The conventional still have given a yield of 2,814 $\mathrm{ml} / \mathrm{m}^{2} /$ day and $2,351 \mathrm{ml} / \mathrm{m}^{2} /$ day for water depth of $5 \mathrm{~cm}$ and $10 \mathrm{~cm}$ respectively [8]. This various improvements made us to work on the still productivity improvement by increasing evaporation and condensation rate. Another novel method of enhancing the evaporation is physically stirring, agitating or spraying of basin water using external energy. During these processes, water mass split into small particles which in- creases the surface area contact between air and water in turn helps in diffusing the water particles into vapour. Mohammed and Zhao [9] used a small wind turbine to stir water using impeller. Khaled [10] de- signed and demonstrated a new still with vibrator to vibrate the still which agitated the basin water leading to the increase of production rate from 3.4 to 5.8 $1 / \mathrm{m}^{2}$ day.

\section{EXPERIMENTAL SETUP AND PROCEDURE}

In this work, two stills were designed, fabricated and constructed to compare the performance of the solar desalination system. One of them is a conventional type and the other is the modified still with inbuilt condenser and agitator as shown in Figs. 2, 3 and 4.

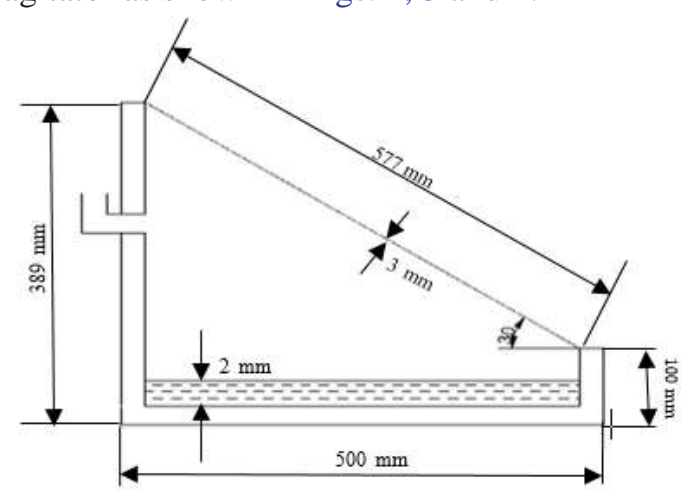

Figure 2. Schematic diagram of conventional solar still 


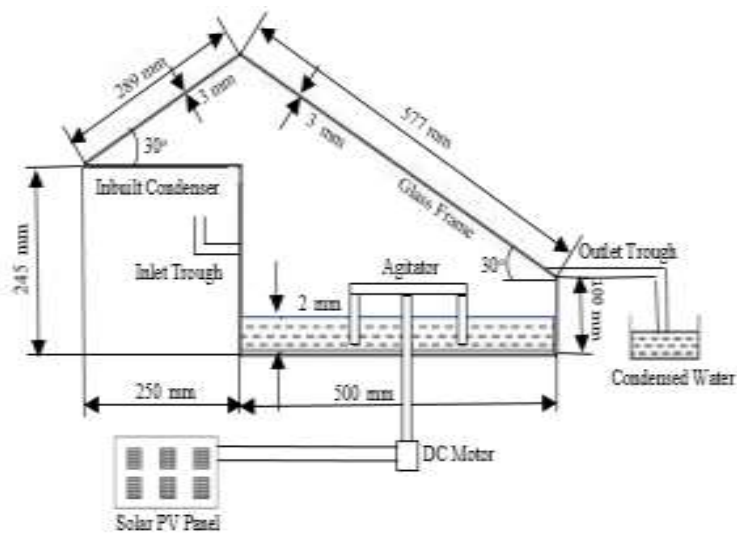

Figure 3. Schematic diagram of modified solar still

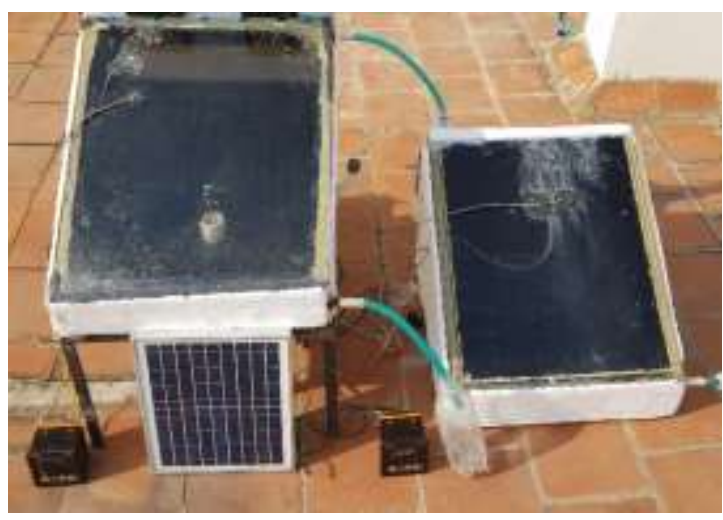

Figure 4. Experimental setup of conventional and modified still

The conventional still is made from stainless steel 304 sheet $(1.02 \mathrm{~mm}$ thick) with a basin area of $0.25 \mathrm{~m}^{2}(500 \mathrm{~mm} \times 500$ $\mathrm{mm})$. The low-side wall height is kept at 100 $\mathrm{mm}$ and the high side wall depth is $389 \mathrm{~mm}$ for $30^{\circ}$ inclination. The inner walls of the basin are coated with black to improve the absorptivity. The still is insulated at the bottom and side walls with thermocole of 20 $\mathrm{mm}$ thickness to reduce the heat loss from the still to ambient. The basin is covered with glass cover of $3 \mathrm{~mm}$ thickness. The gaps between the glass cover and the still was coated with glazy putty to prevent leakage to the atmosphere. The modified still is also made from stainless steel 304 sheet $(1.02$ $\mathrm{mm}$ thick) with a basin area of $0.25 \mathrm{~m}^{2}(500$ $\mathrm{mm} \times 500 \mathrm{~mm}$ ) and inbuilt condenser area of $0.125 \mathrm{~m}^{2}(250 \mathrm{~mm} \times 500 \mathrm{~mm})$. The low- side wall height is kept at $100 \mathrm{~mm}$ and the high side wall depth is $245 \mathrm{~mm}$ for $30^{\circ}$ inclination at both sides. In addition to that a shaft coupled with a de motor of $12 \mathrm{~V}$ capacity for agitation effect is attached. The agitator was attached $0.5 \mathrm{~mm}$ above the bottom surface of basin through the shaft. DC motor were powered by using a solar PV panel. Table I shows the accuracy, range and error of the different instruments used. Experimentation was carried out to analyse the comparative performance of the conventional and modified stills with inbuilt condenser and agitator at Ramco Institute of Technology $\left(9.4536^{\circ} \mathrm{N}, 77.5433^{\circ} \mathrm{E}\right)$. Both the stills were tested under same atmospheric condition to study the exact improvement in performance of the still. Both the stills were maintained at 2 $\mathrm{cm}$ of water level depth. The solar radiation, atmospheric temperature, basin temperature, basin water temperature, glass temperature and distilled water productivity were measured for every half an hour.

\section{RESULTS AND DISCUSSION}

Experimentation was carried out during sunny days of March month, between 7:00 am to 5:00 pm. Figure 5 shows the variation of input parameters such as solar intensity, ambient temperature and wind velocity with time. Solar intensity and ambient temperature reaches maximum around $12.00 \mathrm{pm}$ to $2.00 \mathrm{pm}$ because of abundant perpendicular solar radiation during these hours, but it is low in the morning and the late evening session. Wind velocity is minimum during start of the experimental hour and it keeps on increasing and reaches maximum during the end of the experimental hour. Figure 6 and 7 show the graph plotted for temperatures against time in conventional and modified solar still respectively. Temperatures reaches maximum during peak hours as the solar intensity reaches maximum. From the experimentation carried out, it was observed that the modified system showed a better output is twice than the conventional system. Comparison of productivity of conventional and modified stills against time duration is shown in Figure 8. Improvement in the productivity of the still was due to the agitation effect and 
inbuilt condenser. Agitation effect breaks the surface boundary layer of the water. This leads to water disturbance and increases the surface area of contact between water and air leading to increase in rate of evaporation. Inbuilt condenser increases the condensation rate where the speed of the agitator is maintained at constant speed rate of 60 RPM. Comparison of Total Dissolved Salts (TDS) in PPM of conventional and modified stills is shown in Figure 9. This graph is plotted for ppm calculated before and after desalination. ppm decreases from 508 (salt water) to 130 (Fresh Water) in conventional solar still whereas in modified solar still ppm decreases from 508 (salt water) to 126 (Fresh Water). PPM content is measured using the TDS meter before and after the experimentation. Since the TDS of water below $500 \mathrm{ppm}$ is potable, the collected water from the solar still is good for drinking purpose

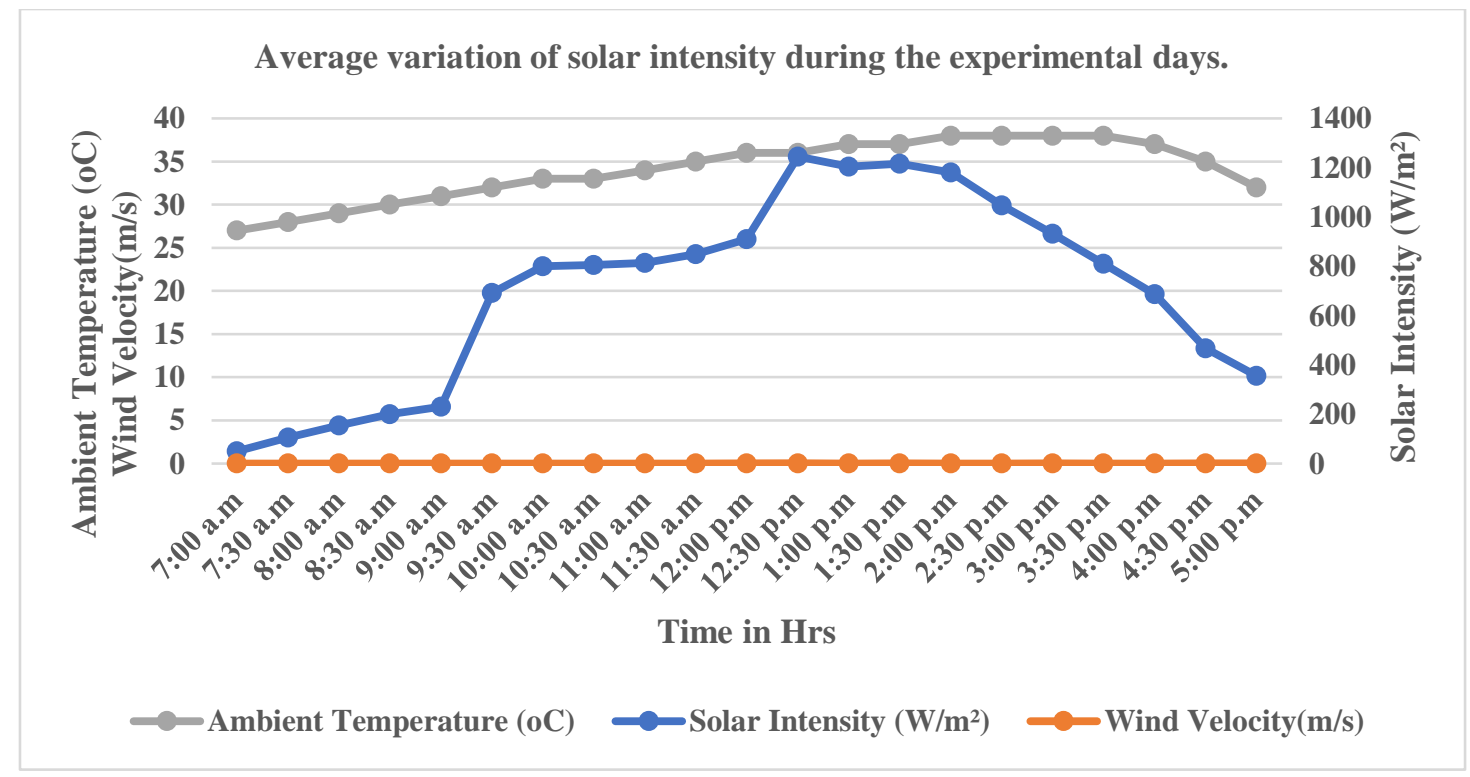

Figure 5. Average variation of solar intensity during the experimental days

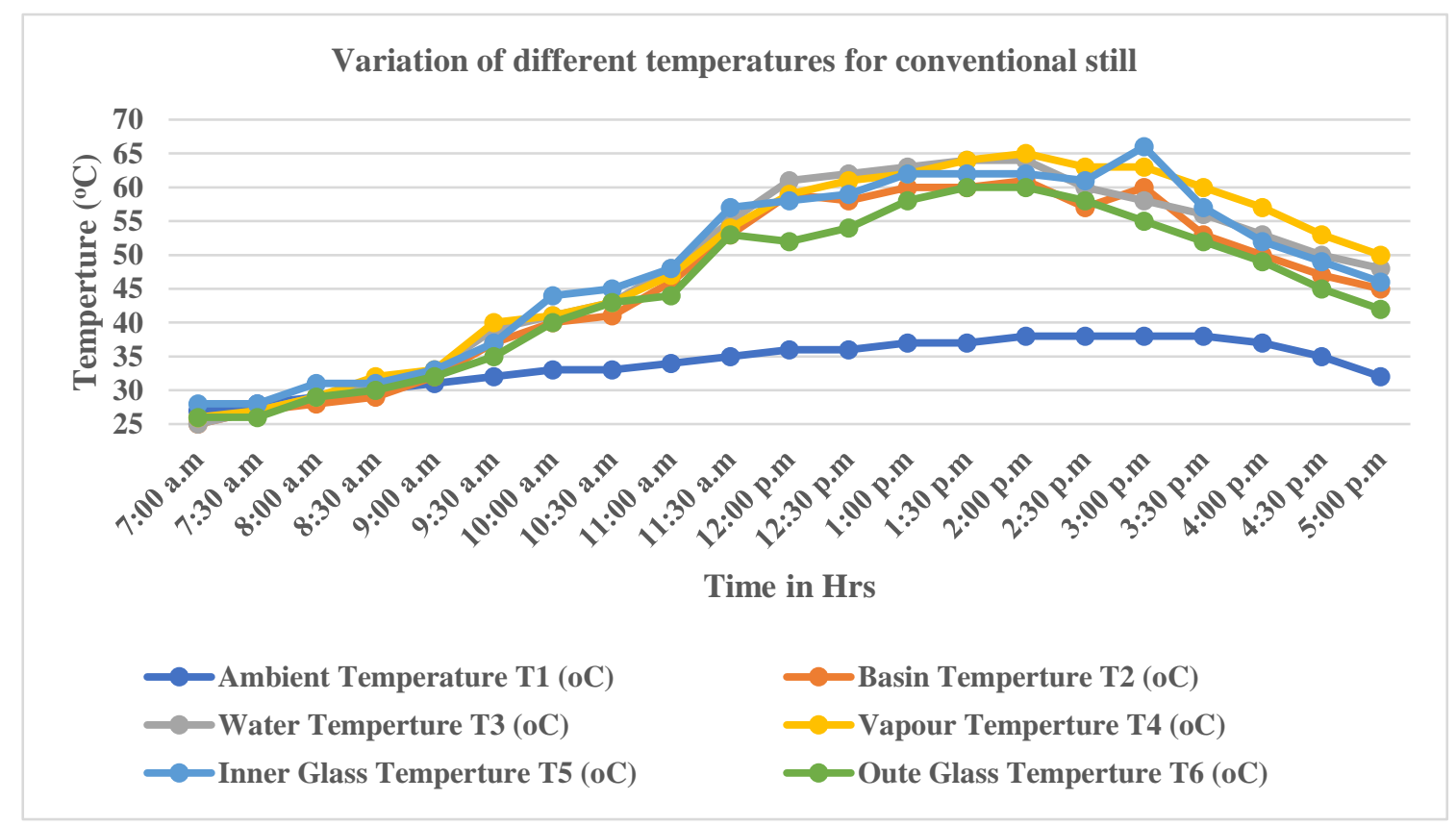

Figure 6. Variation of different temperatures for conventional still 


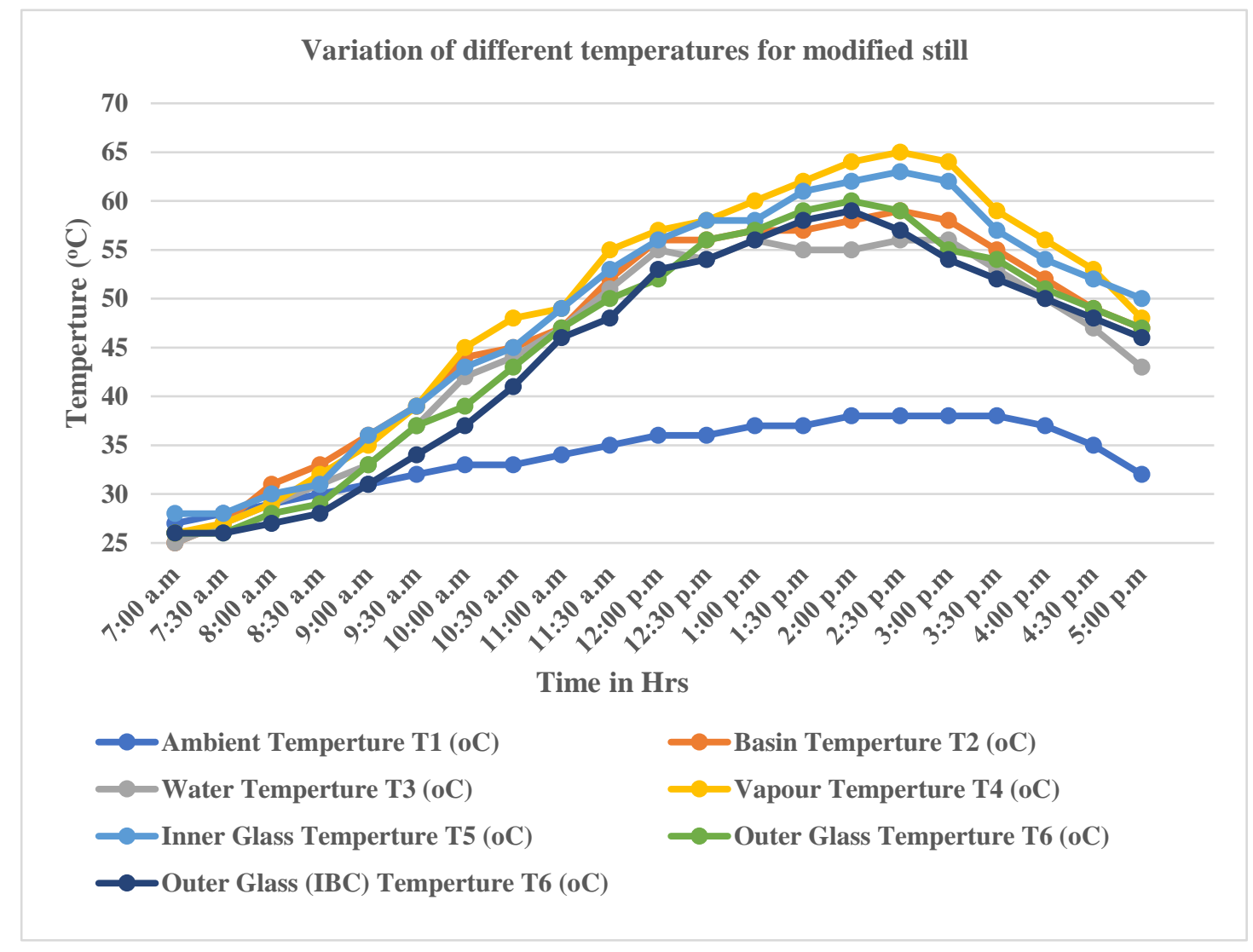

Figure 7. Variation of different temperatures for modified still

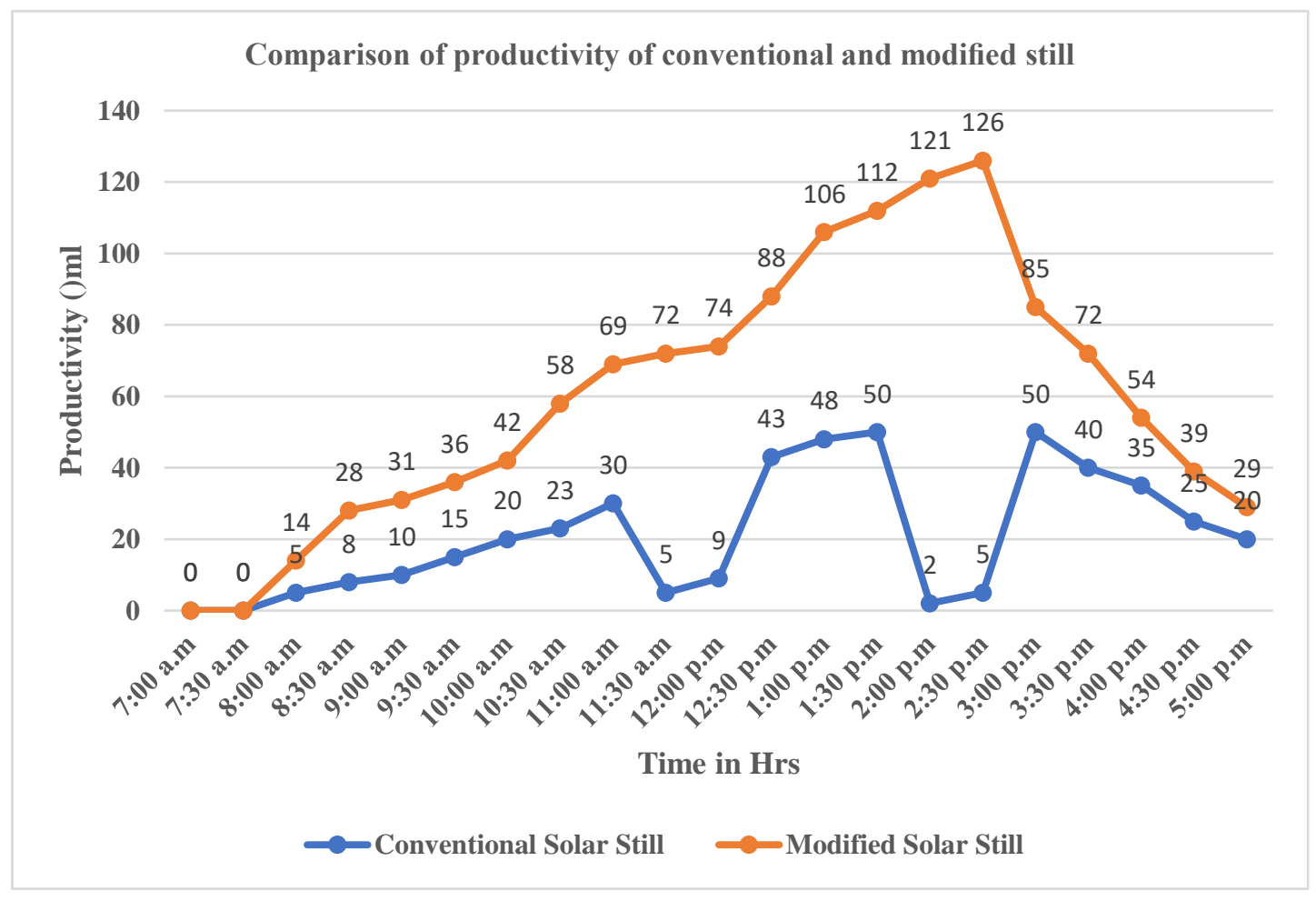

Figure 8. Comparison of productivity of conventional and modified still 


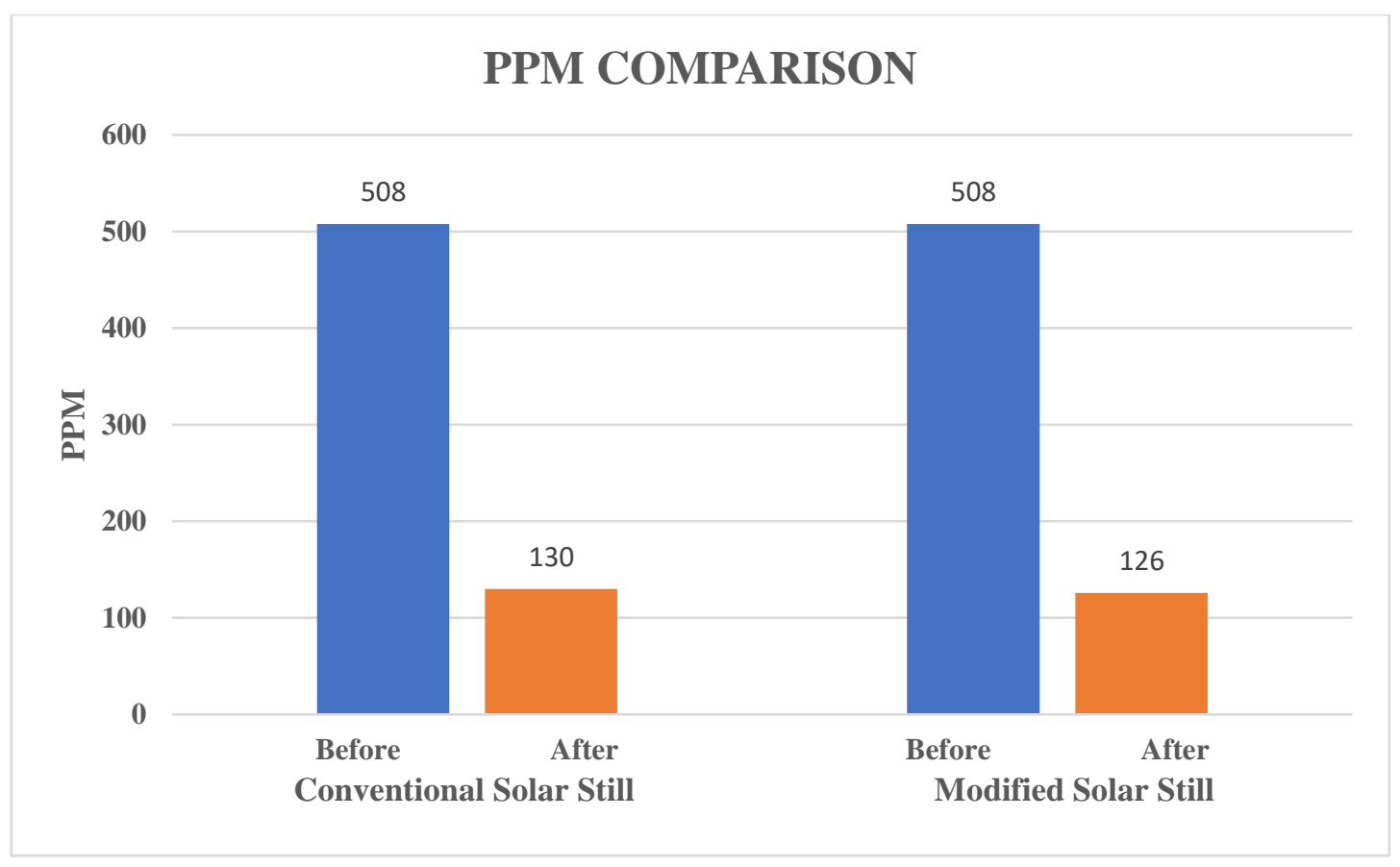

Figure 9. PPM Comparison

\section{EFFICIENCY COMPARISON}

Efficiency of the still can be calculated by using following formula [11] $\eta=(\Sigma \mathrm{m} \times \mathrm{hfg}) /(\mathrm{A} \times \Sigma \mathrm{Is})$

Where, $h f g=(2500.8-2.36 \mathrm{~T}+0.0016 \mathrm{~T} 2-$ $0.00006 \mathrm{~T} 3)$

Where, $\Sigma \mathrm{m}=$ Summation of hourly condensate production per unit area.

$\mathrm{Hfg}=$ latent heat of water

A $=$ area of the absorber plate

$\Sigma$ Is $=$ Average solar radiation .

The efficiency of the conventional still was calculated based on the basin area of $0.25 \mathrm{~m}^{2}$. For the modified still, the solar receiving area was calculated based on basin area of $0.25 \mathrm{~m}^{2}$, inbuilt condenser area of $0.125 \mathrm{~m}^{2}$ and PV panel area of $0.0625 \mathrm{~m}^{2}$. Efficiency of conventional still is $8.29 \%$ for the yield of $0.611 \mathrm{~kg} / \mathrm{day}$ and for the modified still is $13.63 \%$ for the yield of 1.256 $\mathrm{kg} /$ day.

The productivity of the conventional and the modified stills were calculated per $\mathrm{m}^{2}$ area available for solar radiation. The condensate yield from the conventional still is $2.444 \mathrm{~kg} / \mathrm{m}^{2} / \mathrm{day}$ and that of the modified still is $5.024 \mathrm{~kg} / \mathrm{m}^{2} /$ day.

\begin{tabular}{|c|l|c|c|c|}
\hline Sl.No. & Instruments & Accuracy & Range & \% Error \\
\hline 1 & Thermometer & $+1{ }^{\circ} \mathrm{C}$ & $\begin{array}{c}0-100 \\
{ }^{\circ} \mathrm{C}\end{array}$ & $0.25 \%$ \\
\hline 2 & Thermocouple & $+0.1{ }^{\circ} \mathrm{C}$ & $\begin{array}{c}0-100 \\
{ }^{\circ} \mathrm{C}\end{array}$ & $0.50 \%$ \\
\hline 3 & Measuring jar & $+1 \mathrm{~W} / \mathrm{m}^{2}$ & $\begin{array}{c}0-2500 \\
\mathrm{~W} / \mathrm{m}^{2}\end{array}$ & $2.50 \%$ \\
\hline 4 & $\begin{array}{l}\text { PV type sun } \\
\text { meter }\end{array}$ & $+10 \mathrm{ml}$ & $\begin{array}{c}0-1000 \\
\mathrm{ml}\end{array}$ & $10 \%$ \\
\hline 5 & Anemometer & $0.99 \mathrm{~m} / \mathrm{s}$ & $\begin{array}{c}0-30 \\
\mathrm{~m} / \mathrm{s}\end{array}$ & $3 \%$ \\
\hline 6 & Tachometer & $\begin{array}{c} \pm 0.05 \% \\
+1 \mathrm{dgt}\end{array}$ & $\begin{array}{c}6- \\
99,999 \\
\mathrm{rpm}\end{array}$ & $0.05 \%$ \\
\hline
\end{tabular}

Table I. Accuracy, Range and Error of the different instruments used

\section{VII, COST ANALYSIS}

the formulae

Cost comparison can be made by using

Profit $=$ Product value - Annual running cost of still

Annual running cost $=$ First annual cost + Annual maintenance cost - Annual salvage value

The annual maintenance cost is considered as $5 \%$ of the first annual cost. So the maintenance cost of conventional and modified still is Rs.346.5/- and Rs.526.5/respectively. Life time of the still is considered as 10 years and the salvage value as $50 \%$ of first 
annual cost. Salvage value of dc motor and glass is considered as zero at the end of 10 years. Thus the annual decline value for conventional and modified still is Rs.312.5/- and Rs.462.5/- respectively. Input energy used to drive the DC motor for agitation and is obtained from solar radiation using a PV panel. As the cost of the panel is included in first annual cost and the energy obtained is a free energy, the input energy is neglected. Table II shows the comparison between conventional and modified still for various parameters. The market price of the distilled water is Rs. 10 per litre. By using the above formula, profit of the yield from conventional still is Rs.1,174/- per year and that of the modified still is Rs. 2,779/per year. Thus by the above cost analysis, modified still is more effective than the conventional still.

\begin{tabular}{|l|c|c|}
\hline \multicolumn{1}{|c|}{ Type } & $\begin{array}{c}\text { Conventional } \\
\text { Solar Still }\end{array}$ & $\begin{array}{c}\text { Modified } \\
\text { Solar } \\
\text { Still }\end{array}$ \\
\hline Life Time & 10 years & 10 years \\
\hline $\begin{array}{l}\text { First Annual } \\
\text { Cost(Rs.) }\end{array}$ & $6,930 /-$ & $10,530 /-$ \\
\hline $\begin{array}{l}\text { Annual } \\
\text { Maintenance } \\
\text { Cost (Rs.) }\end{array}$ & $346.5 /-$ & $526.5 /-$ \\
\hline $\begin{array}{l}\text { Annual } \\
\text { Decline } \\
\text { Value (Rs.) }\end{array}$ & $312.5 /-$ & $462.5 /-$ \\
\hline $\begin{array}{l}\text { Annual } \\
\text { Salvage } \\
\text { Value (Rs.) }\end{array}$ & $6671.5 /-$ & $10067.5 /-$ \\
\hline Yield & $611 \mathrm{ml}$ & $1256 \mathrm{ml}$ \\
\hline Profit (Rs.) & $1174 /-$ & $2779 /-$ \\
\hline
\end{tabular}

Table II. Comparison between conventional and modified solar still

\section{CONCLUSION}

Conventional and Modified solar still were fabricated. One of the still was attached with a provision to give agitation effect and inbuilt condenser. Both conventional solar still and modified solar still were investigated experimentally at Ramco Institute of Technology, Rajapalayam $\left(9.4536^{\circ} \mathrm{N}, 77.5433^{\circ} \mathrm{E}\right)$. Agitation effect increases the area of contact between the water surface and air by breaking the surface boundary layer of water, leading to enhanced evaporation rate. Inbuilt condenser increases the rate of condensation in it. From the experimentation it was found that the yield of condensate from the modified still was twice than the conventional still. Efficiency of conventional still was found to be $8.29 \%$ and that of modified still was found to be $13.63 \%$. Cost comparison was made between both the stills. Modified still was economically efficient when compared with conventional still. The work can be carried out in future by altering the rpm of the agitator to find out the optimum speed for more evaporation rate and also external condensing fans should be provided for more condensation rate.

\section{ACKNOWLEDGEMENT}

We extent our sincere gratitude to RIT - Research Council for the partial financial support of Rs.7,500/- in the academic year 2018-2019.

\section{REFERENCES}

[1]http://www.indiawris.nrsc.gov.in/wrpinfo/i ndex.php?title $=$ India $\% 27$ s_Water_Wealth

[2]

https://www.kpmg.de/docs/Water_sector_in_I ndia.pdf

[3] Karthikeyan Selvaraj, Alagumurthi Natarajan, 'Factors influencing the performance and productivity of solar stills A Review', Desalination, 2018; 435:181-187.

[4] Muthu Manokar A, Kalidasa Murugavel K, Esakkimuthu G, 'Different parameters affecting the rate of evaporation and condensation on passive solar still - A review', Renewable and Sustainable Energy Reviews, 2014; 38:309-322.

[5] Hamdy Hassan, Saleh Abo-Elfadl, 'Effect of the condenser type and medium of the saline water on the performance of the solar still in hot climate conditions', Desalination, 2017; 417:60-68.

[6] Omara.Z.M., Abdullah A.S., Kabeel A.E., Essa F.A., 'The cooling techniques of the solar stills' glass covers - A Review', Renewable and Sustainable Energy Reviews, 2017; 78:176-193.

[7] Arun Kumar.R, Esakkimuthu.G, Kalidasa Murugavel.K, 'Performance enhancement of a single basin single slope solar still using agitation effect and external condenser', Desalination, 2016; 399:198-202. 
[8] Dr.Bhupendra Gupta, Prem Shankar, Raghvendra Sharma, Dr.Prashant Baredar, 'Procedia Technology, 2016; 25:1209-1216 [9] M.A. Eltawil, Z. Zhengming, Wind turbine-inclined still collector integration with solar still for brackish water desalination, Desalination 249 (2009) $490-497$.
[10].K.M.S. Eldalil, Improving the performance of solar still using vibratory harmonic effect, Desalination 25 (2010) 3-11

[11] Rajaseenivasan, Nelson Raja, Srithar, An experimental investigation on a solar still with an integrated flat plate collector, Desalination 347 (2014) 131-137. 